\title{
Pengaruh Model Pembelajaran Role Playing Terhadap Hasil Belajar Siswa Sekolah Dasar
}

\author{
Mulya Yusnarti¹, Lili Sutyaningsih ${ }^{2}$ \\ 1 Program studi Pendidikan Guru Sekolah Dasar, STKIP Yapis Dompu \\ ${ }^{2}$ Program studi Pendidikan Bahasa dan Sastra Indonesia, STKIP Yapis Dompu \\ E-mail corresponding: mulyayusnarti@gmail.com
}

Article History: Received: 2021-07-22 || Revised: 2021-07-28 || Published: 2021-08-31

Sejarah Artikel : Diterima: 2021-07-22 || Direvisi: 2021-07-28 || Dipublikasi: 2021-08-31

\begin{abstract}
The problem that is answered in this study is "does the role playing model affect student learning outcomes? This type of research is a quasi-experimental research with a quantitative approach. This form uses two groups, one group is given treatment, while the other group is not given treatment. The group that was given treatment was the experimental class with the Role playing learning model, and the group that was not given treatment was the control class with conventional learning. The focus of the presentation in this study is (1) Role playing learning model in class IV C, (2) lecture method in class IV B, (3) pre-test and post-test, (4) even semester, (5), identify role play. The data were analyzed using statistical methods, namely the calculation of the t-test to see the effect of the Role playing learning model by comparing the control class and the experimental class. The statement is indicated by the thiting value $>$ table or $10,181>1,677$. Based on the results of this analysis, it can be stated that there is a significant effect of the Role playing learning model on student learning outcomes in class IV-C (experimental) and class IV-B (control class) at SD Negeri 1 Dompu in the 2019/2020 learning year.
\end{abstract}

Keywords: Influence, Role Playing model. Learning outcomes.

\begin{abstract}
Abstrak
Masalah yang dijawab dalam penelitian ini adalah "apakah model pembelajaran Role playing berpengaruh terhadap hasil belajar siswa?. Jenis penelitian ini ialah penelitian quasi eksperimen dengan pendekatan kuantitatif. Bentuk ini menggunakan dua kelompok, satu kelompok diberikan perlakuan, sedangkan kelompok lain tidak diberikan perlakuan. Kelompok yang diberikan perlakuan yaitu kelas eksperimen dengan model pembelajaran Role playing, dan kelompok yang tidak diberikan perlakuan yaitu kelas kontrol dengan pembelajaran konvesional. Adapun fokus penyajian dalam penelitian ini adalah (1) model pembelajaran Role playing pada kelas IV C, (2) metode ceramah pada kelas IV B, (3) pre-test dan post-test, (4) semester genap, (5). mengindentifikasi bermain peran. Data tersebut dianalisis dengan mengunakan metode statistik yaitu dengan perhitungan t-tes dapat melihat pengaruh model pembelajaran Role playing dengan membandingkan kelas kontrol dan kelas eksperimen. Peryataan tersebut ditandai dengan nilai $t_{\text {hiting }}>t_{\text {abel }}$ atau 10,181>1,677. Berdasarkan hasil analisis tersebut maka dapat dinyatakan bahwa ada pengaruh yang signifikan model pembelajaran Role playing terhadap hasil belajar siswa di kelas IV-C (eksperimen) dan kelas IV-B (kelas kontrol) di SD Negeri 1 Dompu tahun pembelajaran 2019/2020.
\end{abstract}

Kata kunci: Pengaruh, Model Pembelajaran Role Playing. Hasil Belajar

\section{PENDAHULUAN}

Pendidikan nasional berfungsi mengembangkan kemampuan dan membentuk watak serta peradaban bangsa yang bermartabat dalam rangka mencerdaskan kehidupan bangsa, bertujuan untuk berkembangnya potensi peserta didik agar menjadi manusia yang beriman dan bertaqwa kepada Tuhan Yang Maha Esa, berakhlak mulia, sehat, berilmu, cakap, kreatif, mandiri, dan menjadi warga Negara yang demokratis serta bertanggung jawab. Untuk mencapai butir-butir tujuan pendidikan tersebut perlu didahului oleh proses pendidikan yang memadai. Agar proses pendidikan dapat berjalan dengan baik, maka semua aspek yang dapat mempengaruhi belajar siswa hendaknya dapat berpengaruh positif bagi diri siswa, sehingga pada akhirnya dapat meningkatkan kualitas pendidikan, menurut Undang-undang SISDIKNAS Nomor 20 tahun 2003. 
Pendidikan merupakan usaha yang dilandasi kesadaran dan terencana untuk menciptakan proses pembelajaran dan suasana belajar. Supaya murid dapat mengembangkan potensi diri secara aktif untuk mendapatkan keterampilan, akhlak mulia, kecerdasan, kepribadian, pengendalian diri dan kekuatan spiritual keagamaan yang diperlukan oleh dirinya sendiri dan masyarakat (UU No. 20 Th. 2003, pasal 8), termasuk berkewajiban memberikan dukungan sumber daya dalam penyelenggaraan pendidikan.

Pendidikan merupakan salah satu komponen penting yang berpengaruh terhadap perkembangan dan pembangunan suatu bangsa. Pendidikan juga merupakan agen perubahan, agen sosial kontrol dan pembaharuan. Zaman yang semakin berkembang dan maju menuntut perubahan-perubahan pada sistem pendidikan. Sistem pendidikan di Indonesia yang telah di rancang sedemikian rupa demi terciptanya pendidikan yang berkualitas harusnya di dukung pula oleh komponen komponen penting yang ada di dalamnya, yang memang sangat berpengaruh terhadap berjalan atau tidaknya sistem pendidikan tersebut, diantaranya pendidik (guru, dosen), peserta didik, sarana dan prasarana, dan lain - lain.

Berdasarkan pernyataan diatas, salah satu faktor yang juga berpengaruh terhadap keberhasilan suatu pembelajaran adalah cara pengajaran yang diterapkan oleh guru dalam pelaksanaan proses belajar mengajar. Salah satu hal yang banyak disoroti saat ini dalam dunia pendidikan adalah penggunaan metode-metode belajar yang digunakan guru dalam penyampaian materi saat pembelajaran, karena tuntutan guru untuk tepat waktu dalam menyampaikan materi dan kewajiban guru untuk bisa menjadikan siswanya mengerti dan menguasai materi yang disampaikan menjadikan hal tersebut menjadi sebuah permasalahan yang harus dicari solusinya,

Dari hasil observasi awal dan wawancara dengan Ibu guru yang berinisial "W" (selaku guru wali kelas IV) di SDN 01 Dompu pada tanggal 17 Juli 2019, menunjukkan bahwa: "Kemampuan hasil belajar siswa belum sesuai yang diharapkan pernyataan tersebut ditinjau dari tingkat pemahaman siswa terhadap materi pelajaran selama proses pembelajaran yang dilakukan menyebabkan kurangnya daya serap materi pelajaran yang disampaikan oleh pendidik dan bahkan siswa kurang terlibat secara aktif dalam kegiatan proses pembelajaran. yang dimana capaian hasil belajar siswa tersebut belum sesuai yang diharapkan dengan perolehan nilai rata-rata skor 65, otomatis siswa tersebut belum mencapai kriteria ketuntasan belajar minimal (KKM). Hal ini juga berdampak pada hasil pembelajarannya atau nilai rata-rata masih di bawah stsndar KKM (kriteria ketuntasan maksimal) sebesar 70. (W/17/07/2019)". Berdasarkan uraian diatas bahwasannya keterbatasan siswa terkait tentang kurangnya hasil belajar siswa maka perlu ditingkatkan dengan menerapkan Model pembelajaran. Adapun model yang tepat dan sangat efektif untuk diterapkan yakni dengan menggunakan model role playing yang dimana model pembelajaran ini memiliki kelebihankelebihan untuk meningkatkan hasil belajar siswa. Adapun kelebihan-kelebihan diantaranya yakni sebagai alat penyampaian materi pembelajaran, selain mempermudah guru dalam menyampaikan materi pembelajaran, model pembelajaran ini juga dapat menciptakan suasana pembelajaran yang menyenangkan bagi siswa. Dengan terciptanya suasana pembelajaran yang demikian tentunya akan menumbuhkan semangat siswa untuk mengikuti proses pembelajaran dengan baik dan memahami sepenuhnya materi pembelajaran yang disampaikan. Berdasarkan pernyataan tersebut dapatlah dijadikan landasan bahwa ketidakmampuan siswa terkait dengan kurangnya hasil belajar siswa yakni sangat berkaitan erat dengan tidak variatifnya model pembelajaran yang diterapkan dalam proses pembelajaran. Selain sebagai alat transformasi ilmu Model pembelajaran ini juga dapat menciptakan suasana pembelajaran yang menyenangkan. Oleh sebab itu, keberadaan Model Role Playing dalam proses pembelajaran sangat berpengaruh dalam proses pencapaian tujuan pembelajaran. Oleh karena itu, bertolak dari permasalahan yang dikemukakan di atas serta kelebihan-kelebihan Model pembelajaran role playing, maka penulis berinisiatif mengajukan judul "Pengaruh Model Role Playing terhadap hasil belajar pada Tema 6 cita-citaku (sub tema 1 aku dan cita-citaku) siswa IV SD Negeri 01 Dompu tahun Pembelajaran 2019/2020".

\section{METODE PENELITIAN}

Metode penelitian yang digunakan adalah metode eksperimen, dimana metode eksperimen menurut Sugiyono (2012: 107) metode eksperimen merupakan metode yang menjadi bagian dari metode kuantitatif yang mempunyai ciri khas tersendiri, yaitu dengan adanya kelompok 
kontrolnya. Penelitian eksperimen akan membagi subjek penelitian menjadi dua kelas yaitu kelas pertama adalah kelompok eksperimen yang diberikan perlakuan model pembelajaran Role Playing dan kelas kedua adalah kelas kontrol yang tidak diberikan perlakuan model pembelajaran Role Playing, adapun pendekatan yang digunakan dalam penelitian ini yakni menggunakan pendekatan kuantitatif. Yang mana Penelitian kuantitatif ialah penelitian yang banyak dituntut menggunakan angka mulai dari pengumpulan data, penafsiran data, serta penampilan dari hasilnya. Adapun jenis penelitian yang digunakan dalam penelitian ini yakni dengan menggunakan eksperimen semu (Quasi Experimental Design). Eksperimen semu (Quasi Experimental Design) dapat diartikan sebagai proses pembelajaran yang dilakukan secara sistematis, objektik dan terkontrol untuk memperdiksikan kejadian - kejadian. Dalam eksperimen semu (Quasi Experimental Design) "seorang peneliti melakukan manipulasi perlakuan" (Maman, 2016). Perlakuan tersebut direncanakan terlebih dahulu, misalnya anda ingin meneliti pengaruh besarnya jumlah anggota grup dalam melaksanakan praktikum terhadap penguasaan materi sesaat setelah kegiatan pembelajaran.

Sugiyono (2012: 46) mengelompokkan kelas variabel menjadi dua, yaitu kelas eksperimen dan kelas kontrol."Pemilihan kelompok dilakukan secara purposive sample dengan kemampuan sampel dianggap homogen".Kelompok pertama disebut kelompok eksperimen diberi perlakuan pembelajaran Role Playing dan kelompok kedua disebut kelompok kontrol dengan yang tidak diberikan perlakuan. Selanjutnya kedua kelompok diberikan pre-test agar mengetahui kemampuan awal kedua kelompok. Pre-test diberikan untuk mengetahui kemampuan siswa pada sampel di masing masing kelas, penelitian ini dilaksanakan pada kelas IV SD Negeri 01 Dompu tahun pembelajaran 2019/2020 yang jumlah keseluruhannya 77 orang, maka yang akan diambil sebagai sampel dalam penelitian ini adalah sebesar 52 orang siswa yang terdiri dari dua kelas yakni kelas IVB 26 orang sebagai kelas kontrol dan kelas IVC 26 sebagai kelas eksperimen.

Instrumen yang digunakan yaitu: 1) lembar observasi guru, lembar observasi guru yaitu lembarkerja yang berfungsi untuk mengobservasi dan mengukur tingkat keberhasilan atau ketercapaian tujuan pembelajaran pada kegiatan belajar mengajar dikelas. 2) Lembar observasi siswa, Lembar observasi siswa yaitu lembar untuk mengetahui, mengidentifikasi terkait masalah dalam proses pembelajaran yang mana observasi dalam aktifitas siswa yakni dengan mengamati dan melakukan pencatatan dengan sistematis terhadap gejala-gejala yang diteliti. Sehingga dalam proses observasi merupakan proses yang kompleks dan sistematis. 3) Instrument tes, Instrumen tes digunakan untuk mengetahui dan mendapatkan data prestasi belajar siswa. Tes yang dilakukan oleh guru terhadap siswa bertujuan untuk memperoleh data hasil belajar kognitif yang dimiliki oleh siswa pada Tema 6 cita-cita (Subtema 1 aku dan cita-citaku). Selanjutnya tes yang dilakukan dalam penelitian ini yaitu pemberian penugasan dengan menggunakan instrument tes pilihan ganda.

Teknik analisis data menggunakan 1) Analisis statistik deskriptif Menurut sugiyono (2012: 147) Analisis statistik deskriptif adalah statistik yang di gunakan untuk menganalisis data dengan cara mendeskripsikan atau menggambar data yang telah terkumpul sebagaimana adanya tanpa bermaksud membuat kesimpulan yang berlaku untuk umum atau generalisasi. Penelitian yang dilakukan pada populasi (tanpa diambil sampelnya) jelas akan menggunakan statistik deskriptif dalam analisisnya. Tetapi bila penelitian dilakukan pada sampel, maka analisisnya dapat menggunakan statistik deskriptif maupun inferensial. 2) Analisis statistik inferensial. a) Uji Normalitas, Uji normalitas dimaksudkan untuk mengetahui bahwa data setiap variable yang akan dianalisis berdistrbusi normal. Oleh karena itu, sebelum pengujian hipotesis dilakukan, maka terlebih dahulu dilakukan pengujian normalitas data. Adapun teknik yang digunakan untuk menguji normalitas pada penelitian ini dengan menggunkan Chi Kuadrat ( $x^{2}$ ), (Sugiyono 2012: 172) Uji normalitas dilakukan untuk mengetahui apakah data tes akhir (post-test) terdistribusi normal atau tidak.Uji normalitas dicari dengan menggunakan rumus Chi Kuadrat $\left(x^{2}\right)$.

$$
\begin{array}{cl}
x^{2} \sum \frac{\left(f h-f h^{2}\right)}{f h} & =\text { Keterangan } \\
\boldsymbol{x}^{2} & =\text { Chi kuadrat } \\
\text { Fo } & =\text { Frekuensi hasil pengamatan } \\
\text { Fh } & =\text { Frekuensi hasil harapan }
\end{array}
$$


Rumus $\boldsymbol{x}^{2}$ digunakan untuk menguji signifikan perbedaan frekuensi yang diobservasi fo (frekuensi yang diperoleh berdasarkan data), dengan frekuensi yang diharapkan fh. Apabila $\boldsymbol{x}^{2}$ sama atau lebih besar dari harga kritik $\boldsymbol{x}^{2}$, ada perbedaan antara fo dan fh dan sebaliknya apabila $\boldsymbol{x}^{2}$ lebih kecil dari harga kritik dalam table signifikan, maka tidak ada perbedaan antara fo dan fh (Arikunto, 2018). b) Uji Homogenitas Menurut Arikunto (Aas astria, 2018) bahwa pengujian homogenitas dimaksudkan untuk mengetahui kesamaan (homogen) sampel, yakni seragam atau tidaknya variansi sampel, maka perlu dilakukan pengujian homogenitas varian terlebih dahulu. Lebih lajut (Sugiyono, 2018) untuk mengetahui apakah dua sampel kelompok kontrol dan kelompok eksperimen yang diambil bersifat homogen atau tidak. Setelah diketahui bahwa nilai kedua kelompok homogen, maka dapat digunakan rumus t-test. Adapun uji homogenitas menurut Sugiyono (Aas astria, 2018) menggunakan rumus sebagai berikut:

$$
F=\frac{\text { Variansterbesar }}{\text { Variansterkecil }}
$$

Nilai $\mathrm{F}$ hitung selanjutnya dibandingkan dengan harga $\mathrm{F}$ tabel dengan $\mathrm{dk}$ pembilang = neksperimen1 dan dk penyebut = nkontrol-1. Jika $\mathrm{F}$ hitung $<\mathrm{F}$ tabel, maka dapat disimpulkan varians kedua kelompok homogen. Begitu juga sebaliknya, jika harga $\mathrm{F}$ hitung $>\mathrm{F}$ tabel maka dapat disimpulkan varians kelompok tidak homogen. Dengan kriteria pengujinya taraf signifikan $(\alpha)=0,05$ atau taraf kesalahan 5\%. c) Uji Hipotesis, Pengujian hipotesis dimaksudkan untuk mengetahui pengaruh atau hubungan antara dua variabel independen (X) dengan dependen (Y), (Sugiyono, 2018). Berdasarkan pedoman ketentuan bahwa $\mathrm{n} 1=\mathrm{n} 2$ dan varians homogen maka dapat digunakan rumus t-test dengan polled varians, (Sugiyono 2018) dengan menggunakan rumus sebagai berikut dengan rumus:

$$
t=\frac{\bar{x}_{1}-\bar{x}_{3}}{\sqrt{\frac{\left(n_{1}-1\right) s_{1}^{n}+\left(n_{1}-1\right) s_{n}^{n}}{n_{1}+n_{2}-2}\left(\frac{1}{n_{1}}+\frac{1}{n_{2}}\right)}}
$$

Keterangan:

$\mathrm{t}=$ harga- $\mathrm{t}$

$\bar{x} 1=$ rata-rata kelas eksperimen

$\bar{x} 2=$ rata-rata kelas control

$n 1=$ jumlah sampel pada kelas eksperimen

$n 2=$ jumlah sampel pada kelas control

$S^{2}=$ varians

Selanjutnya nilai t hitung dibandingkan dengan nilai t tabel dengan dengan $\mathrm{dk}$ pembilang $=n_{1}-1$ dan dk penyebut $=n_{2}-1$ dan taraf signifikan (a)=0,05 atau $5 \%$ jika t- hitung $\geq \mathrm{t}$ - tabel, maka Hipotesis diterima, sedangkan apabila t- hitung $\leq \mathrm{t}$ - tabel maka Hipotesis ditolak.

\section{HASIL DAN PEMBAHASAN}

\section{a) Hasil Penelitian}

Data yang diperoleh dalam penelitian ini adalah data yang terkumpul dari tes yang diberikan kepada siswa kelas IV SD Negeri 01 Dompu berupa pretest dan posttest yang diberikan pada kedua kelompok yaitu kelompok eksperimen dan kontrol. Adapun instrument yang digunakan instrument tes yang digunakan pada pre test dan post test dalam penelitian ini meliputi data hasil belajar siswa melalui tes kognitif sebanyak 20 butir soal pilihan ganda (multichoice)

1. Uji Normalitas

Data pada uji normalitas ini diperoleh dari hasil pre-test dan post-test, baik dikelas eksperimen maupun di kelas kontrol. Uji normalitas diujikan pada masing-masing variabel penelitian yaitu pre-test dan post-test kelas eksperimen maupun kelas kontrol. Data dikatakan berdistribusi normalapabila nilai taraf signifikansi hitung lebih besar dari nilai taraf signifikansi $a=5 \%$ dengan perhitungan mengunakan chi kuadrat. Menurut Sugiyono (2011: 174) langkah-langkah pengujian normalitas data dengan chi kuadrat adalah sebagai berikut: 
Tabel 1. Perhitungan Uji Normalitas Nilai Pretest Kelas Eksperimen

\begin{tabular}{l|l|l|l|l|l}
\hline Interval & Fo & Fh & (fo-fh) & (fo- fh) $)^{2}$ & $\frac{(f o-f h)^{2}}{f h}$ \\
\hline $35-40$ & 2 & 0,702 & 1,298 & 1,684 & 2,4 \\
\hline $41-46$ & 4 & 3,4684 & 0,5316 & 0,282 & 0,081 \\
\hline $47-52$ & 8 & 8,8296 & $-0,8296$ & 0,688 & 0,077 \\
\hline $53-58$ & 6 & 8,8296 & $-2,8296$ & 8,006 & 0,906 \\
\hline $59-64$ & 4 & 3,4684 & 0,5316 & 0,282 & 0,081 \\
\hline $65-70$ & 2 & 0,702 & 1,298 & 1,684 & 2,4 \\
\hline & 26 & 26 & 0 & 12,626 & 5,945 \\
\hline
\end{tabular}

Harga fh $=2,7 \%$ × $26=0,702 ; 13,34 \%$ × 26=3,4684; 33,96\% × $26=8,8296 ; 33,96 \%$ × $26=8,8296$;

$13,34 \% \times 26=3,4684 ; 2,7 \% \times 26=0,702$.

Dari hasil perhitungan uji Normalitas eksperimen ditemukan harga Chi kuadrat $=5,945$ harga tersebut selanjutnya dibandingkan dengan chi kuadrat tabel, dengan dk (derajat kebebasan) 6 $1=5$. Bila dk 5 dan taraf kesalahan 5\%, maka harga Chi kuadrat tabel $=11,070$ karena harga Chi kuadrat hitung lebih kecil dari harga Chi kuadrat tabel $(5,945<11,070)$, maka data variabel pretest kelas eksperimen tersebut berdistribusi normal.

Tabel 2. Perhitungan Uji Normalitas Nilai Pretest Kelas Kontrol

\begin{tabular}{l|l|l|l|l|l}
\hline Interval & Fo & Fh & (fo-fh) & (fo- fh) $)^{2}$ & $\frac{(f o-f h)^{2}}{f h}$ \\
\hline $25-31$ & 2 & 0,702 & 1,298 & 1,684 & 2,4 \\
\hline $32-38$ & 5 & 3,4684 & 1,531 & 2,343 & 0,680 \\
\hline $39-45$ & 9 & 8,8296 & 0,170 & 0,028 & 0,003 \\
\hline $46-52$ & 6 & 8,8296 & $-2,829$ & 8,003 & 0,906 \\
\hline $63-59$ & 3 & 3,4684 & 0,486 & 0,236 & 0,063 \\
\hline & 1 & 0,702 & 0,298 & 0,088 & 0,126 \\
\hline
\end{tabular}

Harga fh $=2,7 \%$ × $26=0,702 ; 13,34 \%$ × 26=3,4684; 33,96\% × $26=8,8296 ; 33,96 \%$ × $26=8,8296$; $13,34 \% \times 26=3,4684 ; 2,7 \% \times 26=0,702$.

Dari hasil perhitungan uji Normalitas kontrol ditemukan harga Chi kuadrat $=4,178$ harga tersebut selanjutnya dibandingkan dengan chi kuadrat tabel, dengan dk (derajat kebebasan) 6 $1=5$. Bila dk 5 dan taraf kesalahan 5\%, maka harga Chi kuadrat tabel $=11,070$ karena harga Chi kuadrat hitung lebih kecil dari harga Chi kuadrat tabel $(4,178<11,070)$, maka data variabel pretest kelas kontrol tersebut berdistribusi normal.

Tabel 3. Perhitungan Uji Normalitas Nilai Postest Kelas Eksperimen

\begin{tabular}{l|l|l|l|l|l}
\hline Interval & Fo & Fh & (fo-fh) & (fo- fh) $)^{2}$ & $\frac{(f o-f h)^{2}}{f h}$ \\
\hline $60-66$ & 2 & 0,702 & 1,298 & 1,684 & 2,4 \\
\hline $67-72$ & 2 & 3,4684 & 1,4684 & 2,156 & 0,621 \\
\hline $73-78$ & 8 & 8,8296 & $-0,8296$ & 0,688 & 0,077 \\
\hline $79-85$ & 7 & 8,8296 & $-1,8296$ & 3,347 & 0,379 \\
\hline $86-91$ & 5 & 3,4684 & 1,5316 & 2,345 & 0,676 \\
\hline $92-97$ & 2 & 0,702 & 1,298 & 1.684 & 2.4 \\
\hline & 26 & 26 & 0 & 11,904 & 6,553 \\
\hline
\end{tabular}

Harga fh = 2,7\% × $26=0,702 ; 13,34 \%$ × 26=3,4684; 33,96\% × 26 =8,8296; 33,96\% × 26 = 8,8296;

$13,34 \% \times 26=3,4684 ; 2,7 \% \times 26=0,702$.

Berdasarkan perhitungan ditemukan harga Chi kuadrat $=6,553$ harga tersebut selanjutnya dibandingkan dengan chi kuadrat tabel, dengan dk (derajat kebebasan) 6 - 1= 5. Bila dk 5 dan taraf kesalahan 5\%, maka harga Chi kuadrat tabel $=11,070$ karena harga Chi kuadrat hitung lebih kecil dari harga Chi kuadrat tabel $(6,553<11,070)$, maka data variabel pre-test kelas kontrol tersebut berdistribusi normal. 
Tabel 4. Perhitungan Uji Normalitas Nilai Post-test Kelas Kontrol

\begin{tabular}{l|l|l|l|l|l}
\hline Interval & Fo & Fh & (fo-fh) & (fo- fh) $^{2}$ & $\frac{(f o-f h)^{2}}{f h}$ \\
\hline $35-40$ & 2 & 0,702 & 1,298 & 1,684 & 2,4 \\
\hline $41-46$ & 1 & 3,4684 & $-2,4684$ & 6,0929 & 1,756 \\
\hline $47-58$ & 1 & 8,8296 & $-7,8296$ & 61,3026 & 6,942 \\
\hline $53-58$ & 1 & 8,8296 & -7.8296 & 61,3026 & 6,942 \\
\hline $59-64$ & 2 & 3,4684 & $-1,4684$ & 2,1561 & 0,6216 \\
\hline $60-65$ & 19 & 0,702 & 18,298 & 334,8168 & 476,9427 \\
\hline & 26 & 26 & 0 & 406,0524 & 4,95608 \\
\hline
\end{tabular}

Harga fh $=2,7 \%$ × $26=0,702 ; 13,34 \%$ × 26=3,4684; 33,96\% × $26=8,8296 ; 33,96 \%$ × $26=8,8296$;

$13,34 \% \times 26=3,4684 ; 2,7 \% \times 26=0,702$.

Berdasarkan perhitungan ditemukan harga Chi kuadrat $=6,625$ harga tersebut selanjutnya dibandingkan dengan chi kuadrat tabel, dengan dk (derajat kebebasan) $6-1=5$. Bila dk 5 dan taraf kesalahan 5\%, maka harga Chi kuadrat tabel = 11,070 karena harga Chi kuadrat hitung lebih kecil dari harga Chi kuadrat tabel $(4,95608<11,070)$, maka data variabel pre-test kelas kontrol tersebut berdistribusi normal.

2. Uji Homogenitas

Uji homogenitas dimaksudkan untuk mengetahui apakah sampel yang diambil dari populasi berasal dari variansi yang sama dan tidak menunjukkan perbedaan yang signifikan satu sama lain. Tes statistik yang digunakan adalah Uji F, yaitu dengan membandingkan variansi terbesar dan variansi terkecil. Syarat agar variansi bersifat homogen apabila $\mathrm{F}_{\text {hitung }}$ lebih kecil dari $\mathrm{F}_{\text {tabel }}$ pada taraf signifikansi $a=5 \%$. Berarti data kedua kelompok tersebut homogen. berikut diuraikan langkah-langkah perhitungan uji homogenitas.

a) Menghitung Uji $\mathrm{F}$

Setelah nilai $\left(\mathrm{S}^{2}\right)$ diperoleh dari tabel-tabel perhitungan varian pre-test dan post-test kedua kelas, maka selanjutnya akan diuji varian menggunakan uji $\mathrm{F}$ dalam tabel uji homogenitas.

(1) Menghitung Nilai F Pre-test Kelas Eksperimen dan Kelas Kontrol.

$$
\begin{aligned}
& F=\frac{\text { Varian terbesar }}{\text { Varian terkecil }} \\
& F=\frac{75,686}{66,904} \\
& F=1,13
\end{aligned}
$$

Diperoleh harga $\mathrm{F}_{\text {hitung }}=1,13$ Maka harga $\mathrm{F}_{\text {hitung }}$ tersebut selanjutnya dibandingkan dengan $F_{\text {tabel }}$ serta $\mathrm{dk}$ pembilang $(26-1=25)$ dan $\mathrm{dk}$ penyebut $(26-1=25)$. Berdasarkan dk tersebut dan untuk kesalahan 5\%, maka harga $F_{\text {tabel }}=1,708$. Dalam hal ini berlaku ketentuan bahwa, bila $\mathrm{F}_{\text {hitung }}$ lebih besar dari pada $\mathrm{F}_{\text {tabel, }}$ maka varian tidak homogen. Ternyata harga $F_{\text {hitung }}$ lebih kecil dari pada $F_{\text {tabel }}(1,13<1,708)$. Dengan demikian dapat dinyatakan bahwa varian kedua kelas pre-test tersebut adalah homogen.

(2) Menghitung Nilai F Post-test Kelas Eksperimen Dan Kelas Kontrol

$$
\begin{aligned}
& F=\frac{\text { Varian terbesar }}{\text { Varian terkecil }} \\
& F=\frac{92,2154}{71,546} \\
& F=1,28
\end{aligned}
$$

Diperoleh harga $F_{\text {hitung }}=1,28$ Maka harga $F_{\text {hitung }}$ tersebut selanjutnya dibandingkan dengan $F_{\text {tabel }}$ dengan dk pembilang $(26-1=25)$ dan dk penyebut $(26-1=25)$. Berdasarkan dk tersebut dan untuk kesalahan 5\%, maka harga $F_{\text {tabel }}=1,708$. Dalam hal ini berlaku ketentuan bahwa, bila $\mathrm{F}_{\text {hitung }}$ lebih besar dari pada $\mathrm{F}_{\text {tabel, }}$, maka varian tidak homogen. Ternyata harga $F_{\text {hitung }}$ lebih kecil dari pada $F_{\text {tabel }}(1,28<1,708)$. Dengan 
demikian dapat dinyatakan bahwa varian kedua kelas post-test tersebut adalah homogen.

Tabel 5. Rangkuman Uji Homogenitas.

\begin{tabular}{l|l|l|l}
\hline Kelompok & $\mathbf{F}_{\text {hitung }}$ & $\mathbf{F}_{\text {tabel }}$ & Keterangan \\
\hline Pre-test & 1,13 & 1,708 & $\mathrm{~F}_{\mathrm{h}}<\mathrm{F}_{\mathrm{t}}=$ Homogen \\
\hline Post-test & 1,28 & 1,708 & $\mathrm{~F}_{\mathrm{h}}<\mathrm{F}_{\mathrm{t}}=$ Homogen \\
\hline
\end{tabular}

Dari data di atas, menjelaskan bahwa untuk data Pre-test dan Post-test pada kelompok eksperimen maupun kelompok kontrol dapat diketahui nilai $\mathrm{F}_{\text {hitung }}\left(\mathrm{F}_{\mathrm{h}}\right)$ lebih kecil dari $\mathrm{F}_{\text {tabel }}\left(\mathrm{F}_{\mathrm{t}}\right)$ dan nilai signifikansi lebih besar dari 5\% $(\mathrm{P}>0,05)$, yang berarti bahwa data Pretest dan Post-test kedua kelompok tersebut homogen, sehingga memenuhi syarat untuk dilakukan uji-t.

3. Uji Hipotesis

Untuk menguji hasil Uji-T, jika statistik $t_{\text {hitung }}$ diperoleh lebih besar dari $t_{\text {tabel }}$ maka hipotesis diterima.

(a) Makna Hasil Uji-T Hipotesis

Selain menggambarkan persamaan homogenitas dan normalitas data variabel, output ini juga menampilkan uji signifikansi dengan uji-t menggunakn rumus polled varians yaitu untuk mengetahui ada pengaruh yang nyata (signifikan) variabel (X) terhadap variabel (Y).

(b) Hipotesis

Hipotesis statistik dalam penelitian ini diuji dengan menggunakan uji-t, dengan taraf signifikansi $a=5 \%$. Kriteria hipotesis diterima apabila $t_{\text {hitung }}$ lebih besar dari pada $t_{\text {tabel }}$ pada taraf signifikansi 5\% maka Hipotesis diterima, Selanjutnya dilakukan Uji statistik dengan menggunakan rumus polled varians. Berdasarkan ketentuan bahwa $\mathrm{n}_{1}=\mathrm{n}_{2}$ dan varians homogen maka dapat digunakan rumus t-test dengan polled varians, (Sugiyono 2011: 197) dengan menggunakan rumus dan hasil perhitungan sebagai berikut:

$$
\begin{aligned}
& t=\frac{\bar{x}_{1}-\bar{x}_{2}}{\sqrt{\frac{\left(n_{1}-1\right) s_{1}^{2}+\left(n_{1}-1\right) s_{2}^{2}}{n_{1}+n_{2}-2}\left(\frac{1}{n_{1}}+\frac{1}{n_{2}}\right)}} \\
& t=\frac{80,61-62,65}{\sqrt{\frac{(26-1) 71,546+(26-1) 92,215}{26+26-2}\left(\frac{1}{26}+\frac{1}{26}\right)}} \\
& t=\frac{17,96}{\sqrt{\frac{1788,65+2305,375}{26+26-2}\left(\frac{1}{26}+\frac{1}{26}\right)}} \\
& t=\frac{17,96}{\sqrt{\frac{1788,65+2305,375}{50}\left(\frac{1}{26}+\frac{1}{26}\right)}} \\
& t=\frac{17,96}{\sqrt{\frac{4094,025}{50}(0,038)}} \\
& t=\frac{17,96}{\sqrt{81,8805(0,038)}} \\
& t=\frac{17,96}{\sqrt{3,111459}} \\
& t=\frac{17,96}{1,7639} \\
& t=10,181
\end{aligned}
$$

Selanjutnya nilai $t_{\text {hitung }}$ dibandingkan dengan nilai $t_{\text {tabel }}$ dengan $d k=n 1+n 2-2=26+26-2=$ 50 dan taraf signifikan 0,05 atau $5 \%$, maka $t_{\text {tabel }}=1,675$ (uji dua pihak dengan interpolansi). Dalam hal ini berlaku ketentuan bahwa, bila $t_{\text {hitung }}$ lebih besar dari atau sama dengan $t_{\text {tabel, }}$ maka Hipotesis diterima. Ternyata $t_{\text {hitung }}$ lebih besar dari pada $t_{\text {tabel }}(10,181>1,675)$ dengan 
taraf signifikansi $a=5 \%$ maka Hipotesis diterima, Simpulannya model pembelajaran role playing berpengaruh terhadap hasil belajar siswa.

Tabel 6. Hasil Uji-t Post-test Hasil belajar

\begin{tabular}{l|l|l|l|l}
\hline Kelas & $\mathbf{T}_{\text {hitung }}$ & $\mathbf{T}_{\text {tabel }}$ & $\begin{array}{l}\text { Taraf Signifikan } \\
\mathbf{5 \%}\end{array}$ & Keterangan \\
\hline Eksperimenn & 10,181 & 1,675 & 0,05 & $\begin{array}{l}t_{\text {hitung }}>t_{\text {tabel }} \\
\text { (signifikan) }\end{array}$ \\
\hline
\end{tabular}

Dari hasil analisis tabel di atas dapat dilihat perhitungan $t_{\text {hitung }}$ hasil belajar (post-test) sebesar 10,181. Kemudian nilai $t_{\text {hitung }}$ dikonsultasikan dengan nilai $t_{\text {tabel }}$ pada taraf signifikansi $a=0,05$, diporeleh $t_{\text {tabel }} 1,675$. Hal ini menunjukkan bahwa nilai $t_{\text {hitung }}$ lebih besar daripada $t_{\text {tabel }}\left(t_{\text {hitung }} 10,181>t_{\text {tabel }} 1,675\right)$, maka hipotesis diterima. Artinya terdapat pengaruh yang signifikan Model Pembelajaran Role Playing terhadap Hasil belajar.

\section{b) Pembahasan}

Penelitian ini merupakan penelitian kuasi eksperimen atau quasi eksperimen design sebagai upaya untuk meningkatkan kemampuan siswa Tema 6 (cita-citaku), Subtema 1 (aku dan cita-citaku). Penggunaan model pembelajaran role playing sebagai bentuk inovasi dalam penerapan metode pembelajaran yang biasa di gunakan dalam proses pembelajaran, Berdasarkan hasil penelitian hipotesis dapat diketahui bahwa ada pengaruh yang signifikan Model pembelajaran role playing terhadap hasil belajar siswa SD Negeri 01 Dompu yang diajarkan dengan menggunakan Model pembelajaran role playing pada siswa. Hal ini dapat dilihat dari hasil perhitungan uji-t yaitu thitung lebih besar dari t tabel dengan taraf signifikan 5\%.

Sebelum diberikan perlakuan, kedua kelas diberikan tes awal (pre-tes). Hal ini bermaksud untuk mengetahui ada atau tidaknya perbedaan kemampuan awal siswa antara kedua kelas yaitu kelas eksperimen dan kelas kontrol. Dalam proses pembelajaran dikelas Eksperimen diberikan perlakuan dengan menggunakan Model pembelajaran role playing, penggunaan Model pembelajaran role playing dapat meningkatkan hasil belajar siswa terhadap pelajaran yang diberikan, dan setelah diberikanya perlakuan juga diadakan teks akhir (post-tes) untuk mengetahui ada atau tidaknya peningkatan hasil belajar kedua kelas terutama kelas eksperimen yang diberikan perlakuan khusus yaitu menggunakan Model pembelajaran role playing. peningkatan hasil belajar tersebut dapat dilihat dari nilai rata-rata post-tes pada kelas eksperimen dan kelas kontrol. Kedua kelas tersebut menunjukan adanya peningkatan hasil belajar, Akan tetapi, peningkatan hasil belajar yang paling menonjol ditunjukan oleh kelas eksperimen dengan nilai rata-rata post-tes 80, sedangkan Pada kelas kontrol menunjukan peningkatan sebesar 61,3.

Selain itu juga diketahui masing-masing variabel dalam penelitian ini berdistribusi normal, hal ini dibuktikan dengan uji normalitas, kemudian dilakukan uji homogenitas dengan taraf signifikasi 5\% atau $\mathrm{a}=0,05$, dari hasil perhitungan selanjutnya nilai $t_{\text {hitung }}$ dibandingkan dengan nilai $\mathrm{T}_{\text {tabel }}$ dengan $\mathrm{dk}=\mathrm{n} 1+\mathrm{n} 2-2=26+26-2=52$ dan taraf signifikan 0,05 atau $5 \%$, maka tabel $=1,677$ (uji dua pihak dengan interpolansi). Dalam hal ini berlaku ketentuan bahwa, bila $t_{\text {hitung }}$ lebih besar dari $t_{\text {tabel, }}$ maka hipotesis yang diajuakan diterima, Ternyata $t_{\text {hitung }}$ lebih besar dari pada $t_{\text {tabel }}(10,181>1,677)$ dengan taraf signifikan $a=5 \%$ maka hipotesis diterima. Simpulannya Model pembelajaran role playing berpengaruh terhadap hasil belajar siswa.

\section{SIMPULAN DAN SARAN}

\section{A. Simpulan}

Berdasarkan penelitian yang telah dilakukan tentang pengaruh Model pembelajaran role playing terhadap prestasi belajar siswa SD Negeri 01 Dompu Tahun Pembelajaran 2020/2021 setelah dianalisis dapat diambil kesimpulan sebagai berikut: 1) Terdapat pengaruh hasil belajar siswa yang signifikan dalam penggunaan Model pembelajaran role playing terhadap hasil belajar, 2) Dengan hasil uji-t diperoleh nilai $t_{\text {hitung }}$ sebesar 10,181 dan nilai $t_{\text {tabel }}$ sebesar 1,677 dengan angka signifikansi 0,05 yang berarti Model pembelajaran role playing berpengaruh terhadap hasil belajar sehingga hipotesis diterima. 
B. Saran

Berdasarkan hasil penelitian dan pembahasan, saran yang diperlukan pada penelitian ini diantaranya: 1) Guru memahami setiap langkah Model pembelajaran role playing sehingga guru dapat mengajarkan kepada siswa dengan baik, 2) Aturan yang diterapkan pada kegiatan pembelajaran role playing harus disampaikan secara jelas dan bersifat tegas bagi seluruh siswa.

\section{DAFTAR RUJUKAN}

Anjani Puji Ratna. 2015: 23-24 Pengaruh penggunaan metode Role playing terhadap hasil belajar siswa kelas III Tema keperluan sehari-hari subtema jenis-jenis pekerjaan di SD Negeri Dabasah Bondowoso, Dekan FKIP universitas jember. (Diakses pada tanggal 10 Januari 2020).

Budiansyah. 2017: 161. Penggunaan Metode Role playing untuk meningkatkan hasil belajar Ilmu pengetahuan sosial di sekolah dasar negri Palembang (jurnal), volume.1 no. 2. ISSN:25490591. (Diakses pada tanggal 10 januari 2020).

Enung Nurhasanah. (2021). Pengembangan Multimedia Pembelajaran Sejarah Perkembangan Islam Berbasis Macromedia Flash untuk Meningkatkan Hasil Belajar Mahasiswa. Ainara Journal (Jurnal Penelitian Dan PKM Bidang Ilmu Pendidikan), 2(3), 148-153. Retrieved from http://journal.ainarapress.org/index.php/ainj/article/view/69

Fathirma'ruf. (2021). Pengembangan Game Edukasi Berbasis Flash Sebagai Sarana Belajar Siswa PAUD. Ainara Journal (Jurnal Penelitian Dan PKM Bidang Ilmu Pendidikan), 2(3), 143-147. Retrieved from http://journal.ainarapress.org/index.php/ainj/article/view/68

Kompri. (ed). 2015. Motivasi Pembelajaran perspektif Guru dan Siswa. Bandung: PT Rineka Cipta.

Ma'rifah. 2017. Pengaruh Profesionalis Guru Terhadap PrestasiBelajar Siswa Ips Terpadu Di SMP Negeri 6 Woja. Skripsi Tidak Di Terbitkan. Dompu: Sekolah Tinggi Ilmu Pendidikan Yayasan Penddikan Islam STKIP YAPIS DOMPU).

Mardalena Dwi. 2019. Penerapan Model Pembelajaran Role Playing Untuk Meningkatkan Hasil Belajar Siswa. (Online), volume 7, nomor 1, (http://www.neliti.com. Diakses pada Tanggal 17 Juli 2019).

Sari fitria. 2017. 32 Pengaruh metode bermain peran (Role Playing) terhadap hasil belajar siswa padang. (Jurnal), volume 1. ISSN online: 2598-8131. (Diakses pada tanggal 10 januari 2020)

Shoimin Aris (ed). 2013. 68 Model Pembelajaran Inofatif dalam Kurikulum 2013. Yogyakarta: Arruzz media.

Shoimin Aris (ed). 2013. 68 Model Pembelajaran Inofatif dalam Kurikulum 2013. Yogyakarta: Arruzz media.

Sugiyono. 2012. Metode penelitian kuantitatif kualitatif R\&D Bandung: Alfabeta, CV.

Yayuhandayasari92. Makalah Role Playing. html.2013.05.http://blogspot.com. Diakses pada 10 Juli 2019. 